\title{
A Long Term Trial with Clofazimine in Reactive Lepromatous Leprosy
}

\author{
H. PLOCK \\ Iambi Leprosy Hospital, Singida, Tanzania \\ and \\ D. L. LEIKER \\ Royal Tropical Institute, Amsterdam, The Netherlands
}

\begin{abstract}
A report is given on 17 lepromatous patients, all but one steroid dependant because of repeated, serious reactions, treated with clofazimine in dosages of $100-600 \mathrm{mg}$ daily, for periods up to 5 years. In 14 patients who completed $2 \frac{1}{2}$ years of treatment the average annual decrease of $\mathrm{BI}$ in smears and biopsies was $13 \%$ and $14 \%$ resp., being somewhat slower than after sulphone treatment $(17 \%)$. Out of 6 patients who completed 5 years of treatment 5 became negative, one after 4 years, 4 after $4 \frac{1}{2}$ years. In some patients, however, the decrease of the BI was slow and unsatisfactory. No evidence of resistance to lamprene was found. No correlation was found between slow response and long period of weaning off steroids or with other complications.

The decrease was somewhat slower in patients with long duration of disease and long duration of previous (sulphone) treatment. In this series of patients the overall long-term reaction suppressive effect was somewhat less than in other trials and not better than in patients treated with $100 \mathrm{mg}$ daily. No correlation was found with duration of disease and bacteriological progress.

In this series an unusually high proportion of the patients complained of abdominal pain, vomiting after medication and some of diarrhoea, to the extent that clofazimine treatment had to be discontinued ( 7 out of 17 patients). No correlation was found with duration of disease, duration of previous treatment, steroid dependance or sex. The lower frequency of abdominal complaints reported from trials with lower dosages of clofazimine suggest a relationship with dosage. A history in several patients of severe enteritis or dysentery prior to clofazimine treatment suggests that clofazimine acts as an irritant in particular if the intestines have already become irritable by other factors.
\end{abstract}

The first reports on activity of clofazimine in leprosy (Browne and Hogerzeil, 1962, Browne 1965) have been confirmed by many authors. Several reports, including some on controlled clinical trials (Tolentino et al., 1971) indicate that the antibacteriological activity of clofazimine is of the same order as of DDS. Some studies, however, suggest a somewhat lower activity (Hastings et al., 1969).

The anti-inflammatory properties of clofazimine too, first reported by Browne

\footnotetext{
* Received for publication 9 October, 1975.
} 
(1965) were confirmed by most authors. Pettit (1967) and Karat et al. (1971), however, did not find a significant anti-inflammatory effect using $100 \mathrm{mg}$ clofazimine daily. In other trials (a.o. Leiker, 1970) it was found that although this dosage did not have a rapid effect on reactions, the incidence and severity of reactions in a high proportion of reaction prone lepromatous patients diminished significantly within a year, to the extent that most steroid dependent patients could be weaned of steroids. In other trials with higher dosages of clofazimine (200-600 mg daily) a marked anti-inflammatory effect was found (a.o. Imkamp, 1968, Karat et al., 1970), confirmed in a double blind clinically controlled trial (Helmy et al., 1971). In 2 series of steroid-dependent lepromatous patients, treated with $100 \mathrm{mg}$ and $200-400 \mathrm{mg}$ clofazimine daily, Leiker (1971) did not find a significant difference in the time needed for weaning the patients off steroids. The general impression obtained from the literature is that most patients respond favourably, bacteriologically as well as with respect to the incidence and severity of reactions, but that some patients continue having mild to moderately severe reactions and some patients fail to respond satisfactorily even to higher dosages.

The present study was made to evaluate the long term effect of clofazimine in a

TABLE 1

Complications after clofazimine treatment

\begin{tabular}{|c|c|c|c|c|c|c|c|}
\hline Pat. & Sex/age & $\begin{array}{c}\text { Duration } \\
\text { disease } \\
\text { (years) }\end{array}$ & $\begin{array}{l}\text { Previous } \\
\text { treatment } \\
\text { (years) }\end{array}$ & $\begin{array}{l}\text { Previous } \\
\text { reactions }\end{array}$ & $\begin{array}{c}\text { Steroid } \\
\text { dependance }\end{array}$ & $\begin{array}{c}\text { Daily } \\
\text { dosage } \\
\text { clofazimine }\end{array}$ & $\begin{array}{l}\text { Withdrawal } \\
\text { steroids } \\
\text { after }\end{array}$ \\
\hline 1212 & M35 & 5 & 3 & + & \pm & 300 & 5 weeks \\
\hline 970 & F30 & 7 & 6 & ++ & - & 300 & 2 months \\
\hline 1455 & M45 & 14 & 14 & ++ & - & 200 & not \\
\hline 1228 & M20 & 4 & 3 & ++ & ++ & 300 & 9 months \\
\hline 220 & F35 & 24 & 13 & ++ & ++ & $2-300$ & 27 months \\
\hline 914 & M35 & 9 & 4 & ++ & ++ & $3-400$ & 7 months \\
\hline 1202 & M40 & 11 & 3 & ++ & ++ & 300 & 9 months \\
\hline 349 & M40 & 14 & 9 & ++ & ++ & 300 & not \\
\hline 281 & F35 & 18 & 5 & ++ & ++ & 300 & 4 months \\
\hline 555 & M20 & 12 & 9 & ++ & ++ & 300 & 5 months \\
\hline 1519 & M25 & 3 & 2 & ++ & ++ & 300 & 10 months \\
\hline 1000 & F25 & 15 & 5 & ++ & ++ & 200 & 7 months \\
\hline 1800 & M25 & 4 & 1 & + & + & 400 & 2 months \\
\hline 1170 & M25 & long & 3 & ++ & ++ & 300 & 3 months \\
\hline 712 & M30 & 16 & 8 & ++ & ++ & $2-300$ & not \\
\hline 1673 & F30 & 3 & 2 & ++ & ++ & 400 & not \\
\hline 1590 & M40 & 5 & 2 & ++ & ++ & 300 & 6 months \\
\hline
\end{tabular}


series of patients with advanced lepromatous leprosy, who were prone to repeated, severe reactions prior to the trial, all but one being steroid dependent (Table 1). The duration of clofazimine treatment was up to 5 years.

\section{Dosage of Clofazimine}

In 7 patients treatment was started with $300 \mathrm{mg}$ clofazimine daily; in the others with $100 \mathrm{mg}$ daily, followed mostly by a weekly increase with $100 \mathrm{mg}$ daily, to $300 \mathrm{mg}$ daily, or in a few patients to $400 \mathrm{mg}$ daily, and in one patient to $600 \mathrm{mg}$ daily. One patient was given only $200 \mathrm{mg}$ daily. The drug was given in divided doses, in order to promote resorption of the drug. Treatment was continued as long as accepted by the patient or until smears had become negative. The drug was reduced to $100 \mathrm{mg}$ daily when reactions had subsided or had become mild.

\section{Assessment}

Skin smears were taken at 2 monthly intervals, each time at 5 sites. They were examined locally by the same technician. Skin biopsies were taken at 4-6 months

\begin{tabular}{|c|c|c|c|}
\hline Reactions af ter clof azimine & $\begin{array}{l}\text { Abdominal } \\
\text { pain }\end{array}$ & $\begin{array}{l}\text { Discontinuation of } \\
\text { clof azimine }\end{array}$ & $\begin{array}{l}\text { Other } \\
\text { complications }\end{array}$ \\
\hline occasional, mild & + & temp. 3 months & \\
\hline none & - & not & \\
\hline less frequent, less severe & \pm & temp. 1 month & dysentery \\
\hline rare, mild & + & $\begin{array}{l}\text { temp. } 7 \text { months } \\
\text { temp. } 3 \text { months } \\
\text { stop after } 46 \text { months }\end{array}$ & \\
\hline $\begin{array}{l}1 \text { year frequent, moderate } \\
\text { thereaf ter rare, mild }\end{array}$ & - & - & \\
\hline occasional, mild & - & - & \\
\hline single only & - & - & $\begin{array}{c}\text { diabetes } \\
\dagger \text { apoplexy }\end{array}$ \\
\hline less frequent, less severe & + & $\begin{array}{l}\text { temp. } 1 \text { month } \\
\text { stop after } 55 \text { months }\end{array}$ & $\dagger$ pneumonia \\
\hline occasional, slight & _- & - & \\
\hline $\begin{array}{l}\text { period of neuritis, } 4 \text { months } \\
\text { temp. steroids }\end{array}$ & + & stop after 46 months & $\begin{array}{l}\dagger \text { nephrotic } \\
\text { syndrome }\end{array}$ \\
\hline mild, after 1 year none & + & stop after 34 months & \\
\hline temp. steroids 7 months & + & stop after 32 months & \\
\hline slight to moderate & - & - & \\
\hline one serious, thereafter none & + & stop after 31 months & $\begin{array}{l}\dagger \text { nephrotic } \\
\text { syndrome }\end{array}$ \\
\hline less frequent, less severe & - & - & $\begin{array}{l}\dagger \text { unspec. } \\
\text { infection }\end{array}$ \\
\hline severe, frequent & + & stop after 19 months & \\
\hline none & + & temp. twice 2 months & $\begin{array}{l}\dagger \text { resp. } \\
\text { infection }\end{array}$ \\
\hline
\end{tabular}


TABLE 2

Infiltration Index biopsies (\% infiltration in section)

\begin{tabular}{|c|c|c|c|c|c|c|c|c|c|c|c|c|c|}
\hline Months & 0 & 4 & 10 & 14 & 18 & 22 & 26 & 30 & 34 & 39 & 44 & 52 & 57 \\
\hline 1212 & 20 & 20 & 25 & 40 & 20 & 5 & 5 & 10 & 5 & 5 & 5 & 2 & 2 \\
\hline 970 & 10 & 15 & 5 & 10 & 2 & 5 & 15 & 5 & 5 & 5 & 2 & 2 & 2 \\
\hline 1455 & 15 & 30 & 30 & 15 & 5 & 10 & 10 & 10 & 5 & 2 & 10 & 10 & 10 \\
\hline 1228 & 10 & 20 & 10 & 20 & 5 & 2 & 10 & 5 & 5 & 5 & 2 & 2 & 2 \\
\hline 220 & 25 & 15 & 10 & 10 & 5 & 5 & 5 & 5 & 10 & 10 & 2 & 2 & 2 \\
\hline 914 & 70 & 30 & 10 & 5 & 5 & 5 & 2 & 5 & 2 & 20 & 2 & 2 & $\dagger$ \\
\hline 1202 & 40 & 15 & 15 & 20 & 25 & 30 & 30 & 25 & 30 & 30 & 20 & $\dagger$ & \\
\hline 349 & 20 & 50 & 40 & 50 & 25 & 20 & 20 & 80 & 25 & 40 & 30 & & \\
\hline 281 & 15 & 35 & 25 & 10 & 15 & 25 & 15 & 5 & 25 & 10 & 10 & 2 & 5 \\
\hline 1000 & 20 & 60 & 80 & 20 & 15 & 25 & 40 & 20 & 15 & 25 & 20 & 15 & 2 \\
\hline 555 & 10 & 40 & 20 & 15 & 20 & 20 & 15 & 30 & 15 & 5 & 5 & $\dagger$ & \\
\hline 1519 & 30 & 10 & 10 & 5 & 20 & 5 & 10 & 10 & 5 & 2 & & & \\
\hline 1800 & 15 & 10 & 5 & 10 & 5 & 10 & 5 & 5 & 5 & 2 & & & \\
\hline 1170 & 30 & 10 & 10 & 20 & 25 & 2 & 5 & 2 & 5 & 5 & $\dagger$ & & \\
\hline Average & 24 & 26 & 21 & 18 & 14 & 12 & 13 & 16 & 11 & 12 & & & \\
\hline
\end{tabular}


intervals, when possible each time from the same lesion. They were processed and examined in Amsterdam. The Bacterial and Morphological Indices were assessed blindly.

\section{Clinical Results}

Clinically all patients responded rapidly to the drug with reduced infiltration of the skin and puffiness of the face. After the initial favourable response the clinical improvement became more gradual and slow. The reduction of the visible infiltration in general corresponded with the decrease in infiltration index (Table 2).

\section{Bacteriological Results}

Because all patients had previously received treatment, intact bacilli were rarely found. The majority of the bacilli were granular at the onset of the trial. In most patients the BI decreased gradually in smears (Table 3) and in biopsies (Table 4), but on the average the decrease was relatively slow. In a few patients no significant decrease was found.

The average BI in smears at onset was 2.0 and in biopsies 4.5. After $2 \frac{1}{2}$ years the average BI had decreased in 1.3 and 3.0 respectively, corresponding with an average annual decrease of $14 \%$ and $13 \%$ respectively. During the trial 6 out of 17 patients became bacteriologically negative in smears and biopsies.

\section{Effect on Reactions}

In most patients ENL reactions occurred, frequently accompanied by neuritis, arthralgia, tibial pains (periostitis, osteitis), swelling of hands and feet or, rarely by orchitis. In a few patients, ENL being absent or very mild, the latter symptoms were predominant. They were counted as reactions.

After the introduction of clofazimine fresh reactions were seen in most patients. Only after several months of treatment did the reactions become less frequent and severe, indicating a lag phase in the suppression of reactions. In 8 patients the reactions subsided completely after 2-13 months of treatment, with an average of 7 months. Four of these patients had transient relapses of reactional phases, 2 after fading out of steroid therapy, one after an interruption of specific treatment and reintroduction of clofazimine and one after replacement of clofazimine by DDS. In one patient, af ter 2 months of treatment, the reactions improved from severe to mild and became infrequent, but only after 33 months did they subside completely. Another patient became free of reactions only after 54 months, when smears had become negative. In another patient mild, occasional reactions continued until 1 year af ter smears had become negative.

One patient continued with very mild reactions for 4 years, after which he left the trial. Five patients never became completely free of reactions during the trial, although the reactions became less frequent and severe. Fourteen patients were completely steroid dependent. In 11 patients, after an average period of 10 months, steroid treatment could be discontinued. In 2 patients the dosage of prednisolone could be reduced, but low steroid dosages were needed throughout the trial. In 1 patient a dosage of $30 \mathrm{mg}$ prednisolone daily had to be maintained. In 2 patients, after weaning off steroids, prednisolone treatment had to be resumed temporarily for periods of 5 and 8 months respectively. 
TABLE 3

Bacterial Index in smears

\begin{tabular}{|c|c|c|c|c|c|c|c|c|c|c|c|c|c|c|c|c|c|}
\hline Months & 0 & 4 & 7 & 11 & 14 & 18 & 22 & 26 & 30 & 33 & 39 & 43 & 46 & 50 & 54 & 57 & 61 \\
\hline 1212 & 3.2 & 2.2 & 1.6 & 1.4 & 1.4 & 1.4 & 1.2 & 1.0 & 0.8 & 0.8 & 1.2 & 0.8 & 1.4 & 0.4 & 0 & 0 & 0 \\
\hline 970 & 1.4 & 0.8 & 0.6 & 0.8 & 1.0 & 0.6 & 0.8 & 0.4 & 1.0 & 0.6 & 0.8 & 0.8 & 0.4 & 0.8 & 0 & 0 & 0 \\
\hline 1455 & 1.8 & 1.6 & 1.6 & 1.4 & 1.6 & 1.8 & 1.6 & 1.0 & 1.2 & 1.6 & 1.0 & 0.6 & 0.8 & 0.4 & 0 & 0 & 0 \\
\hline 1228 & 2.2 & 1.0 & 0.8 & 1.0 & 0.8 & 1.0 & 0.8 & 0.6 & 0.8 & 0.4 & 1.0 & 0.8 & 0.4 & 0.8 & 0 & 0 & 0 \\
\hline 220 & 2.0 & $(1.8)$ & 1.6 & 1.2 & 1.0 & 1.6 & 1.0 & 0.8 & 0.6 & 0.4 & 1.0 & 1.0 & 0.6 & 0 & 0 & 0 & 0 \\
\hline 914 & 1.4 & 2.0 & 1.6 & 2.0 & 1.8 & 1.8 & 1.6 & 1.8 & 1.4 & 1.8 & 2.0 & 1.6 & 0.8 & 0.6 & & & \\
\hline 1202 & 1.2 & $(1.2)$ & 1.2 & 1.2 & 1.0 & 1.6 & 1.0 & 0.6 & 1.0 & 0.8 & 1.0 & 0.8 & 1.4 & 0.8 & $\dagger$ & & \\
\hline 349 & 2.4 & 2.6 & 3.0 & 2.4 & 2.8 & 2.6 & 2.4 & 2.4 & 3.0 & 1.6 & 1.4 & 2.0 & $\dagger$ & & & & \\
\hline 281 & 2.2 & 1.8 & 1.8 & 1.8 & 2.0 & 2.2 & 1.8 & 1.6 & 2.2 & 1.6 & 1.6 & 1.8 & 1.8 & 1.0 & 0 & 0 & 0 \\
\hline 1000 & 1.6 & 2.4 & 1.8 & 1.6 & 2.6 & 2.6 & 1.8 & 2.4 & 2.8 & 2.8 & 1.2 & 1.4 & 1.2 & 1.0 & 0 & 0.2 & 0 \\
\hline 555 & 3.2 & 2.2 & 1.8 & 2.0 & 2.4 & $(2.1)$ & 1.8 & 2.2 & 1.8 & 1.6 & 1.2 & 2.4 & 1.4 & 1.2 & $\dagger$ & & \\
\hline 1519 & 1.1 & 1.0 & 1.2 & 1.2 & 1.0 & 1.0 & 0.6 & 0.8 & 0.4 & 1.0 & 0.4 & & & & & & \\
\hline 1800 & 2.6 & $(2.4)$ & 2.0 & 2.0 & 1.8 & 1.6 & 1.6 & 1.6 & 1.0 & 2.2 & 1.0 & 1.2 & 0 & & & & \\
\hline 1170 & 1.0 & 1.4 & 1.0 & 0.6 & 0.6 & 0.6 & 0.6 & $(0.6)$ & 0.6 & 0 & 0 & $\dagger$ & & & & & \\
\hline Average & 2.0 & 1.8 & 1.5 & 1.5 & 1.6 & 1.6 & 1.3 & 1.3 & 1.3 & 1.2 & 1.1 & & & & & & \\
\hline 712 & 3.6 & 3.0 & 3.4 & 2.8 & 2.8 & 0.6 & $\dagger$ & & & & & & & & & & \\
\hline 1673 & 2.0 & 2.0 & 2.0 & 3.3 & 1.8 & 1.4 & 1.8 & 1.2 & 1.4 & 0.2 & 0.6 & 0.6 & & & & & \\
\hline 1590 & 2.4 & 2.8 & 3.6 & 3.2 & $\dagger$ & & & & & & & & & & & & \\
\hline
\end{tabular}


TABLE 4

Bacterial Index in biopsies

\begin{tabular}{|c|c|c|c|c|c|c|c|c|c|c|c|c|c|}
\hline Months & 0 & 4 & 10 & 14 & 18 & 22 & 26 & 30 & 34 & 39 & 44 & 52 & 57 \\
\hline 1212 & 3.5 & 4.0 & 5.0 & 5.0 & 6.0 & 4.0 & 4.0 & 2.0 & 3.0 & 3.0 & 1.0 & 0.5 & 0 \\
\hline 970 & 4.0 & 2.0 & 3.0 & 2.0 & 3.0 & 3.0 & 3.0 & 4.0 & 3.0 & 3.0 & 3.0 & 0.5 & 0 \\
\hline 1455 & 6.0 & 3.0 & 3.5 & 3.0 & 3.0 & 3.0 & 2.0 & 1.0 & 1.0 & 0 & 0 & 0 & 0 \\
\hline 1228 & 2.0 & 3.5 & 4.0 & 2.0 & 3.0 & 3.0 & 1.0 & 3.0 & 3.0 & 2.0 & 0 & 0 & 0 \\
\hline 220 & 3.5 & 3.0 & 4.0 & 3.0 & 3.0 & 3.0 & 4.0 & 3.0 & 3.0 & 1.0 & 0 & 0 & 0 \\
\hline 914 & 4.0 & 4.0 & 4.5 & 4.0 & 4.0 & 4.0 & 4.0 & 4.0 & 4.0 & 3.0 & 2.0 & 1.0 & \\
\hline 1202 & 3.5 & 5.0 & 4.0 & 4.0 & 4.0 & 1.0 & 1.0 & 3.0 & 2.0 & 1.0 & 1.0 & $\dagger$ & \\
\hline 349 & 6.0 & 6.0 & 6.0 & 5.0 & 4.5 & 4.0 & 2.0 & 4.0 & 4.0 & 3.0 & $\dagger$ & & \\
\hline 281 & 6.0 & 6.0 & 6.0 & 6.0 & 4.0 & 5.0 & 4.0 & 4.0 & 3.0 & 3.0 & 0 & 0 & 0 \\
\hline 1000 & 6.0 & 6.0 & 6.0 & 6.0 & 6.0 & 6.0 & 5.0 & 6.0 & 4.0 & 4.0 & 3.0 & 1.0 & 0 \\
\hline 555 & 6.0 & 6.0 & 6.0 & 6.0 & 6.0 & 4.0 & 4.0 & 5.0 & 5.0 & 3.0 & 3.0 & $\dagger$ & \\
\hline 1519 & 4.0 & 4.0 & 3.0 & 3.0 & 3.0 & 2.0 & 2.0 & 3.0 & 4.0 & 1.0 & & & \\
\hline 1800 & 5.0 & 4.0 & 4.0 & 4.0 & 3.0 & 4.0 & 4.0 & 0 & 0 & 0 & & & \\
\hline 1170 & 4.0 & 4.0 & 1.5 & 1.0 & 1.0 & 1.0 & 1.0 & 0 & 0 & 0 & $\dagger$ & & \\
\hline Average & 4.5 & 4.3 & 4.3 & 3.9 & 3.8 & 3.4 & 2.9 & 3.0 & 2.9 & 1.9 & & & \\
\hline
\end{tabular}




\section{Other Complications}

In this trial a high percentage of the patients, 10 out of 17 , developed more or less severe abdominal pain. In 3 patients the complaints were moderately severe, requiring temporary interruption of clofazimine treatment for periods of 1-3 months. In 7 patients the complaints were severe and persistent and clofazimine treatment had to be discontinued ultimately, after an average period of treatment of 38 months. In most patients the pain was located in the stomach region, but in 2 patients an enteritis with the clinical picture of dysentery was seen.

The outcome of fractional tests of the stomach contents was not consistent. Hyperacidity as well as hypoacidity and normal acidity were found. In 2 patients barium contrast X-ray screening revealed a large, hypotonic stomach with gross gastritis.

The stomach complaints subsided in most patients soon after withdrawal of clofazimine, but in 1 patient they persisted after discontinuation of the drug. During the trial it was found that 1 patient suffered from a latent diabetes, which later became manifest. This patient died of apoplexy. In 3 patients albuminuria was found. The patients had very advanced disease of long duration, with a long history of reactions. Two of these patients died after a nephrosis syndrome.

Three other patients died after secondary infections, pneumonia, descending upper respiratory tract infection and an unidentified infection respectively.

Two patients were pregnant and delivered during the trial. One child died after 3 hours. The cause of death could not be clarified. The mother of this child was steroid dependent, but 4 weeks before delivery prednisolone was discontinued. The second child was healthy.

\section{Discussion}

In 14 patients who completed $2 \frac{1}{2}$ years of treatment with clofazimine the $\mathrm{BI}$ in smears decreased from an average of 2.0-to 1.3 and in biopsies from 4.5 to 3.0, corresponding with an average annual decrease of $13 \%$ and $14 \%$ resp. This is somewhat slower as compared with patients on sulfone treatment (on the average about 17\%). Of the 6 patients who completed 5 years of treatment 5 became negative, one after 4 years and 4 after $4 \frac{1}{2}$ years of treatment. On the other hand in some patients the bacteriological response to clofazimine was decidedly slow and unsatisfactory. Resistance to clofazimine is unlikely because the patients had not received clofazimine prior to the trial and the response to clofazimine was already disappointing in the first years of the trial. Resistance to clofazimine has not yet been reported.

No correlation was found between a slow bacteriological response and a long period needed for weaning of steroids ( $>6$ months), not with stomach complaints. The decrease in BI was somewhat slower in patients with a very long duration of the disease $(>10$ years) and with a long duration of previous treatment $(\geqslant 5$ years $)$.

In the first months of treatment, in spite of dosages of 3-400 mg clofazimine daily, several patients continued with moderate to severe reactions. The lag phase in the effect of clofazimine suggests that it is dependant on the building up of a deposit of the drug in the tissues. Several other patients continued with mild reactions throughout the trial. One patient continued to suffer from frequent and severe reactions, in spite of $400 \mathrm{mg}$ clofazimine daily. One patient remained steroid dependent. The overall results of this trial, with respect to the suppression 
of reactions by clofazimine, are somewhat less favourable than those that have been reported from other trials and they are not significantly better than those that have been reported from trials with $100 \mathrm{mg}$ clofazimine daily. No correlation was found between the effect of clofazimine on the reactions and the duration of the disease or the bacteriological response to treatment. No explanation for the less favourable effect of clofazimine in some patients was found.

Mild to moderate gastro-intestinal complaints have been reported from other trials. In this trial a very high incidence of abdominal pain was found. In several patients the complaints were severe, with excessive pain and vomiting after each medication. Some patients refused to take the drug again after temporary discontinuation, for fear that the pain might recur.

In a few patients, after conventional treatment of gastritis or after treatment of latent amebiasis or, if a secondary intestinal bacterial infection was suspected, after treatment with sulphonamides, it was possible to reintroduce clofazimine, with a better tolerance. In 7 patients clofazimine had to be withdrawn completely. No correlation was found with long duration of disease (5 out of 9 patients with a history of $>10$ years) or with long previous treatment ( 3 out of 6 patients with $\geqslant 5$ years treatment) or with steroid dependance ( 9 out of 14 steroid dependent patients) or with the time needed for withdrawal of steroids ( 7 out of 10 patients who continued with steroids for $\geqslant 6$ months). Also no correlation was found with sex ( 8 out of 12 males and 2 out of 5 females). In the majority of other trials lower dosages of clofazimine have been used or the higher dosages have been administered for shorter periods, and the duration of the clofazimine treatment has been shorter. In some of the patients in this trial the complaints subsided after reduction of the dosage. This suggests that the complaints are to some extent dose related.

In several of the patients a history of severe enteritis or dysentery was found in the records. This suggests that clofazimine acts as an irritant in particular if the intestines have already become irritable by other factors. Though the present trial confirms that many patients greatly benefit from clofazimine treatment, it also shows that for some patients it is not the final answer to their problems.

\section{References}

Browne, S. G. (1965a). B.663-possible anti-inflammatory action in lepromatous leprosy. Lepr. Rev. 36, 9.

Browne, S. G. (1965b) Treatment of Leprosy with "B.663"-Appraisal of the pilot trial after three years. Lepr. Rev. 36, 13.

Browne, S. G. (1966). B.663 (Geigy). Further observations on its suspected anti-inflammatory action. Lepr. Rev 37, 141.

Browne, S. G. and Hogerzeil, L. M. (1962). B.663 in the treatment of leprosy. Preliminary report of a pilot trial. Lepr. Rev. 33,6 .

Devadason, C. (1969). B.663 (Geigy 30.320) in the treatment of leprosy. A preliminary report. Acta trop. 26, 265.

Hastings, R. C., Trautman, J. R. and Mansfield, R. E. (1969). Antibacterial effects of G. 30.320 Geigy (B.663) in lepromatous leprosy. Derm. intern. 8, 21.

Helmy, H. S., Pearson, J. M. H. and Waters, M. F. R. (1971). Treatment of moderately severe erythema nodosum leprosum with clof azimine-a controlled trial. Lepr. Rev. 42, 167.

Imkamp, F. M. J. H. (1968). A treatment of corticosteroid-dependent lepromatous patients in persistent erythema nodosum leprosum. A clinical evaluation of G. 30320 (B.663). Lepr. Rev. 39, 119.

Karat, A. B. A., Jeevaratnam, A., Karat, S. and Rao, P. S. S. (1970). Double-blind controlled clinical trial of clofazimine in reactive phases of lepromatous leprosy. Br. med. J. 198. 
Karat, A. B. A., Jeevaratnam, A., Karat, S. and Rao, P. S. S. Controlled clinical trial of clofazimine in untreated lepromatous leprosy. Br. med. J. 514.

Leiker, D. L. (1970). Treatment of leprosy with Geigy B.663 (G. 30320). E. A. Lepr. Bull. 1, No. 2,9 .

Leiker, D. L. (1971). Chemotherapy of leprosy. Int. J. Lepr. 39, 464.

Pettit, J. H. S. (1967). The treatment of erythema nodosum leprosum with B.663. A controlled study. Int. J. Lepr. 35, 11.

Tolentino, J. G., Rodriguez, J. N., Ababon, R. M. (1971). Controlled drug trial of B.663 compared with DDS. Preliminary (48 week) report. Int. J. Lepr. 39, 738. 